\title{
MARITAL STATUS, CAREER AND INCOME AS INDICATORS OF LIFE SATISFACTION AMONG MIDDLE-AGED CAREER WOMEN IN HULU LANGAT, SELANGOR, MALAYSIA
}

\author{
Siti Marziah Zakaria ${ }^{1}$, Nor Ba'yah Ab. Kadir ${ }^{1}$, and Khairul Hisyam Baharuddin²
}

${ }^{1}$ Psychology and Human Well-being Research Centre, Universiti Kebangsaan Malaysia, 43300, Bangi, Selangor, Malaysia, ${ }^{2}$ Centre for Language and Generic Development, Universiti Malaysia Kelantan, 16300, Bachok, Kelantan, Malaysia

\begin{abstract}
Korespondensi: Siti Marziah Zakaria (e-mail: marziah@ukm.edu.my/ sitimarziah80@ukm.edu.my)
\end{abstract}

\begin{abstract}
Life satisfaction is a subjective construct that varies according to gender, education level, age, income, marital status, and other demographic factors. Life satisfaction is an important issue among middle-aged women. They face various responsibilities, roles and expectation at this age. The objective of this article is to identify the differences in life satisfaction among middleaged Malay women from different educational level, marital status, career and income. This study applied a survey technique, which is a set of questionnaire which consisted of sociodemographic scale and life satisfaction scale (based on Life Satisfaction Index - Short Form by Barrette and Murk, 2006). Simple random sampling and purposive sampling have been used to obtain the responses. A total of 410 middle-aged career women in Hulu Langat, Selangor have participated in this study. The finding showed that life satisfactions among middle-aged women are different depending on their marital status, career and income. This was based on the result of ANOVA. Single women and widower who are working in private sector and of low-income level reported to have the lowest life satisfaction. This finding may provide input to the planning of programs to enhance the well-being and life satisfaction among middle aged career women.
\end{abstract}

Keywords: middle-aged women, life satisfaction, marital status, career, income.

\section{Introduction}

Women in their middle age might experience physical, cognitive and emotional changes. They have to accept the fact that their capabilities are declining in certain areas. Changes in the values of life are also common during the middle age phase after they had encountered various experiences. Their views towards religion have also changed in- line with the changes in their perspectives of life (Costello, 2012). These changes would affect their perception on life satisfaction and happiness. At this stage, they are making choices, choosing what action should be taken, considering how to allocate time and resources and evaluating all aspects in life (Santrock, 2011). Middle-aged individuals would start to review where they had been 
and what they had been doing in life. They will look forward on how much time remains for them to do the things they wanted in life (Santrock, 2011).

Life satisfaction is an important issue among middle-aged women. They face various responsibilities, roles, and expectation at this age. Middle age is supposedly a 'vacation' for women since their children are all grown up, having a stable job, and their marriages have also reached maturity. However, they need to carry a variety of demands and challenges in this phase (Navaie, Spriggs \& Feldman, 2002). They are occasionally forced to bear a number of responsibilities as a mother, daughter, wife, grandmother, and as a worker at the same time (Berg, 2011). Women also have to prepare themselves to accept the changes in their family structure. The increase or reduction of family members, such as the presence of in-laws and their grandchildren or the death of their partners and parents, may greatly affect their life satisfaction.

In reality, life satisfaction is a subjective construct that varies according to gender, education level, age, income, marital status, and other demographic factors (Zhang, Erping \& Chan, 2011). For example, Chipperfield and Havens (2001) found that women and men who have experienced marriage failures were reported to have low life satisfaction. Shichman and Cooper (2004), on the other hand, found that education level, income, and marriage are the main factors for life satisfaction. For seniors and the elderly, financial and physical aspects are more significant in affecting life satisfaction. Age is also related to life satisfaction, as proven by Jan and Masood (2008). With age increment, life satisfaction was found to decrease by $40 \%$.

Ministry of Women, Family and Community Development, Malaysia (2017) is very concerned about the welfare of women in
Malaysia. This ministry aims at uplifting the participation of women in the development of country. Women should be the contributor and the recipient of the benefits of prosperity. The ministry is very committed in safeguarding the rights of women in all sectors. Women should be treated equally and deserve no discrimination. Women also should have access to involve in political, economic and social sector. Thus, this study will help to realize the vision of the ministry. The results of this study will help ministry to revise, plan and develop programs to enhance life satisfaction and well-being of women, especially middle-aged women. Thus, the objective of this study is to identify the differences in life satisfaction of middleaged women from various marital, education, occupation and income background. The identification of groups with lowest level of life satisfaction will help to strategize the plan and reassess the policy for the betterment of women's life satisfaction.

\section{Literature Review}

Life satisfaction is the most important and stable component of a person's subjective well-being besides the affective component (Kim-Prieto, et.al., 2005). An individual who has high life affluence was reported to have high level of life satisfaction and positive mood as well as emotional well-being (Suldo \& Huebner, 2005). Life satisfaction was also defined as person's subjective evaluation of the degree to which his or her most important needs, goals, and wishes have been fulfilled (Valois, et.al., 2004). Diener (1999) suggested that there are some components in life satisfaction, such as desire to change life, satisfaction with current life, satisfaction with past, satisfaction with future, and significant others' views of one's life. 
Life satisfaction is commonly studied in a few countries like Australia (NATSEM, 2010), the United States of America (Meeks and Murrel, 2001), the Netherlands (Kapteyn, Smith \& Soest, 2009), Canada (Gee and Veevers, 1990), Sweden (Berg, 2011; Borg, Hallberg \& Blomqvist, 2005), Japan (Yamasaki, Nelson \& Omori, 2011), China (Leung, Moneta \& Chang, 2005; Song and Appleton, 2008), India (Hasnain, Ansari \& Sethi, 2011), and more. The study on life satisfaction was conducted on various samples including the elderly (Ramachandran and Radhika, 2012; Sener, 2011; Song, 1992), from adulthood to death (Hutchinson, Simeon, Bain \& Wyatt, 2004), teenagers (Kong and You, 2013), university students (Mahanta and Aggarwal, 2013), women (Jan and Masood, 2008) and workers from various sectors (Adams, King \& King, 1996; Jessica, Johnson, Pitt \& Smyer, 2008). Nevertheless, the study on life satisfaction among middle-aged women is still not well explored in Malaysia. The level of life satisfaction among middle-aged women from different backgrounds is also yet to be further explored. Studies done overseas conversely reported various findings on the level of life satisfaction from different backgrounds.

For example, studies have found no significant differences in the life satisfaction scores for single, married, and divorced women (Jan and Masood, 2008). The factor for their life satisfaction is definitely varied as suggested by Kousha and Moheen (2004) who conducted a study among Iranian women living in urban areas. For married women, their life satisfactions are influenced by the marriage quality, work, and social activities. For single women, their life satisfactions are mainly influenced by social activities and level of education. This is similar to a study done in German where it was found that the factors influencing life satisfaction varied between women with spouses and women without spouses (Albert, 2010). For women living with their spouses, satisfaction in their family influenced life satisfaction generally. For women living alone, satisfaction in friendship and socio-economic status are more influential. For them, satisfaction in family is less important in determining their life satisfaction (Albert, 2010).

Studies on education background and life satisfaction were done by several overseas researchers. Jan and Masood (2008) reported that there were differences in general life satisfaction between women of different levels of education. The differences in personal life satisfaction are found to have no significant dissimilarities between illiterate and highly educated women. There is a high level of personal life satisfaction among highly educated women. Highly educated women have more opportunities in the economic field and workforce. Sousa and Lyubonmirsky (2001) suggested that there will be a higher life satisfaction among women when they have the same income and education opportunities as men.

Meeks and Murrell (2001) also conducted a study on 1,177 seniors aged 55 years old and above. They were interviewed four times in 6 months. The study found that life satisfaction was related to education and negative emotions. A higher level of education conversely will decrease the level of negative emotions. Additionally, a lower negative emotion would contribute to higher life satisfaction and better health. Negative emotions, at the same time, mediate between education and healthy aging. This shows that education is an important foundation for healthy aging.

Nonetheless, there are also studies that negatively relate education and life satisfaction or harmony. For example, a study done in 
Australia has found that respondents whose level of education was Grade 11 and below have higher life and work satisfaction as compared to respondents with higher education level. Respondents with Degrees, Masters and $\mathrm{PhD}$ are reported to have lower life satisfaction averagely (Gong, Cassells \& Keegan, 2011). Respondents from different levels of education might have different evaluations on life satisfaction and sources for life satisfactions. Age also plays an important role where majority of the respondents who have low education level are mostly aged 50 years old and above and respondents who are university graduates are the younger generation.

Zhang, et.al. (2011) compared income and social status based on the occupation groups of the respondents. The finding of the study showed that occupation groups predicted the life satisfaction of the Chinese community from 2005 to 2009. A lower occupation group has shown a lower level of life satisfaction. As proven by Sheldon, et.al., (2001), the level of life necessity achievement can be related positively with the level of life satisfaction. A study by Easterlin et al., (2012) also found that the lowest social class reported a deteriorating life satisfaction. Conversely, a higher social class experienced improving life satisfaction.

Income was also found to be related to life satisfaction at urban areas in China. A higher household income was related to a higher life satisfaction (Song and Appleton, 2008). Unemployment was found to have been reducing life satisfaction promptly. In a study by Jan and Masood (2008) in Kashmir and Jammu, a comparative study between personal and household income was conducted. The researchers found that a higher personal income contributed to greater life satisfaction. A similar relationship pattern also occurred between household income and life satisfaction.
A study done by Berg, et.al. (2009) reported that divorce or death of spouse had a significant effect on life satisfaction, especially to male respondents. Gender difference indicates differences in role and responsibilities in marriages. Marriage conveys different meaning for men and women, especially from a psychosocial perspective. With the loss of spouse, it would be normally difficult for men to takeover home duties that were done by the wife previously (Berg, et.al., 2009). Loss of spouse also means loss of partner who are often the closest friend upon entering middle age (Chappel, 1989).

Life satisfaction has been studied in Indonesia as well. For example, research done by Khoerun Nisa (2014) analysed the influence of resources towards life satisfaction of retiree. This research was done in West Java. It applied cross sectional design and purposive sampling technique that involved 30 male and 30 female elderly who have passed minimum of one year retirement period. The result showed that the retirement resource ranked in medium category. There was no differences in life satisfaction between male and female elderly. The education, the per capita income, and the resource would increase life satisfaction in elderly. The regression test showed that resources affect life satisfaction positively among elderly in retirement phase (Khoerun Nisa, 2014).

This current study, on the other hand, will re-examine the differences of life satisfaction among middle-aged career women from diverse educational level, marital status, career and income. These variables were selected as past researches showed inconsistent results. Past researches have examine life satisfaction in multiple samples, contexts and locations. Observation on samples found that most of studies in life satisfaction focused on elderly or late adults as their samples. This 
study, nonetheless, focuses only on middleaged career women as this group of subjects is expected to have established their career, have achieved the goal in life, and have found a new life perspectives. This group is in the process of assessing and reviewing their life. Thus, a study on life satisfaction is critical and very relevant to this group. As Erik Erikson proposed the stage of generativity vs stagnation to middle-aged women.

\section{Methodology}

\section{Research Sample}

This study was carried out at three districts in Hulu Langat, Selangor which are Ampang, Kajang and Cheras. It involved middle-aged career women from different demographic characteristics (marital status, education background, employment status and health status). A total of 410 respondents were selected for this study. The mean age of respondents is 49 years old. Respondents were selected from both private and public sectors in Hulu Langat, Selangor. Statistics reported that Selangor have a total number of 2,972 ('000) labour force, which contributed to $21.3 \%$ of total labour force in Malaysia. The number of total labour force in urban areas in Selangor outnumbered the rural area. Comparatively, 1, 654 ('000) are male labours compared to 1,131 ('000) female labours (Department of Statistics, 2014).

The sampling methods used were simple random sampling and purposive sampling. Simple random sampling was done to select three districts out of seven districts in Hulu Langat, Selangor for the study. The districts selected were Kajang, Ampang and Cheras. Purposive sampling was done to get the sample of the study. Women who fulfilled the criteria were selected to participate in the study.
The criteria are Malay women, aged between 40 and 59 years old, working and living in Ampang, Kajang or Cheras, and have careers (either in the government or private sector or self-employed). Out of the 500 questionnaires distributed, 410 questionnaires were returned.

Career women were selected as they represented a high percentage of population in the state of Selangor. They work in many sectors, mainly services and sales (29\%), administrative work (17.7\%) and management, as professionals (14.8\%). Thus, women in Selangor play a major role in developing the economic and social aspects. Selangor is one of the developed states in Malaysia. The number of career women is higher in urban areas compared to rural area (KPWKM, 2015). Furthermore, the number of career women or working women is increasing from 2010 to 2014, as reported by KPWKM (2015). In $2012,49.5 \%$ of women participated in labour force. It increased to $52.4 \%$ in 2013 , and $53.6 \%$ in 2014. In reality, they joined labour force for multiple reasons. Economic factor, better level of education, increasing cost of living and preferring a career life perhaps are the main reasons of joining labour force.

\section{Research Design and Instruments}

This study has utilized questionnaires to get feedbacks from the respondents. The life satisfaction of middle-aged Malay women in Hulu Langat, Selangor was studied using Life Satisfaction Index A-Short Form by Barret and Murk (2006). The index contained 12-scales with reliability value of 0.79 . The index was tested on various levels of age, especially on the middleaged and seniors. There were five life satisfaction components studied in the index comprising of zest of life, strength and determination, similarities between achieved and envisioned goals, positive self-concept and mood tone (Barret and Murk, 
2006). The feedbacks on the item are based on a 4-Likert scale: Strongly disagree, Disagree, Agree, and Strongly Agree.

\section{Data Analysis}

The objective of this study was answered using ANOVA test (Analysis of Variance) by analysing One-Way ANOVA. SPSS programme was used to analyse the data. The mean value and $F$ were given attention to get the accurate answer of the differences in life satisfaction among middle-aged women from various backgrounds. Test of significance was observed to determine whether the differences in mean are significant or significant. The value of $p$ will decide the acceptance or rejection of the hypotheses.

The hypotheses that were tested in this study are as follows.

Ho1: There are no differences in life satisfaction between middle-aged women from different marital statuses.

Ho2: There are no differences in life satisfaction between middle-aged women from different educational levels.

Ho3: There are no differences in life satisfaction between middle-aged women from different career sectors.

Ho4: There are no differences in life satisfaction between middle-aged women from different income levels.

\section{Results}

The first ANOVA analysis was done on marital status (Table 1). Marital status was divided into two categories, single/ divorced/ widowed, and married. It was clear that different marital status contributed to different life satisfaction. The value of $F=11.40$ was found to be significant at $p<0.01$. The highest min value recorded by married women was 36.68. Single/divorced/widowed women recorded a low life satisfaction (mean 34.69). Life pressures originating from financial problems, various responsibilities, and the public's stigma may affect the achievement of their life satisfaction. Levene test showed a similarity in variances of the studied marital status categories, married and single (3.81, p $>0.05$ ). This implies a variety in the score for each of the same category.

Education level was also studied because previous findings showed that education can affect life satisfaction. The highest education level, which is university/ college showed highest life satisfaction, followed by primary and secondary school (Table 2). This may be due to the effect of education on the current career and income. It was clear that college/ university education background has affected women's perception on life satisfaction as they have a good position in the society and have a cosy life. Nevertheless, the $F$ value recorded

Table 1 Life Satisfaction from Different Marital Statuses

\begin{tabular}{lllll}
\hline Marital Status & N & M & SD & F \\
\hline Single/ Divorced/ Widowed & 82 & 34.69 & 5.47 & $11.40^{\star *}$ \\
Married & 320 & 36.68 & 4.55 & \\
\hline
\end{tabular}

${ }^{* *} p<0.01$

Source: SPSS 18 
Table 2 Life Satisfaction from Different Education Level

\begin{tabular}{lllll}
\hline Education level & N & M & SD & F \\
\hline Primary school and lower & 26 & 35.92 & 4.29 & 2.77 \\
Secondary school & 212 & 35.78 & 4.77 & \\
College/ university & 165 & 36.94 & 4.88 & \\
\hline
\end{tabular}

$p>0.05$

Source: SPSS 18

a low score of 2.77, $p>0.05$. This showed an insignificant difference between different levels of education on life satisfaction.

The difference of life satisfaction of women from different careers was also conducted. Careers were generally sorted according to the category of employer, such as public, private and self-employed. Statistic from the labour force indicated that majority of Malay women work at public sectors compared to women from other races. Thus, the data showed that there were 221 women in the public sector as compared to 68 women in the private sector. The analysis on the average score of life satisfaction showed that women in the public sector reported the highest life satisfaction followed by self-employed women.

This situation illustrated the work demand and stress faced at the workplace. Women in the private sector may experience higher work stress as compared to women in the public sector and self-employed women, such as those who conduct their own business from home. A distinct average score was shown by the public servant (mean=37.02), compared to private workers and self-employed, with the $F$ value $=7.65, p<0.01$ (Table 3$)$

Moreover, the data indicated that the highest income (> RM5000) experienced the uppermost life satisfaction (mean $=38.28$ ) compared to lower income earners. It is clear that lower income would contribute to a low average value in life satisfactions. The respondents might place income as a criterion to determine life satisfaction. Respondents with the lowest income might feel isolated from the community and felt that they did not deserve to experience the best quality of life. Value of $F=8.46, p<0.01$ showed that there is a significant difference (Table 4). Income played an important role in influencing life satisfaction of middle-aged women.

Table 3 Life Satisfaction from Different Career Sectors

\begin{tabular}{lllll}
\hline Career & N & M & SD & F \\
\hline Public & 221 & 37.02 & 4.69 & $7.65^{\star *}$ \\
Private & 68 & 34.57 & 4.46 & \\
Self-Employed & 114 & 35.82 & 4.97 & \\
\hline
\end{tabular}

${ }^{* *} \mathrm{p}<0.01$

Source: SPSS 18 
Table 4 Life Satisfaction from Different Income Level

\begin{tabular}{lllll}
\hline Income & N & M & SD & F \\
\hline <RM1000 & 80 & 34.61 & 4.41 & $8.46^{\text {** }}$ \\
RM1001-RM3000 & 167 & 35.83 & 4.56 & \\
RM3001-RM5000 & 113 & 37.35 & 4.67 & \\
>RM5001 & 39 & 38.28 & 5.12 & \\
\hline
\end{tabular}

${ }^{* *} \mathrm{p}<0.01$

Source: SPSS 18

In short, analysis on the respondents' profiles indicated that single/divorced/widowed, private sector employees and low-income women were more likely to have the lowest level of life satisfaction. Marital status, career sectors and income levels clearly marked a great impact to their perception towards life satisfaction.

Therefore, the decisions have been made on the established hypotheses. Three null hypotheses need to be rejected. There are as below.

Ho1: There are no differences in life satisfaction between middle-aged women from different marital statuses. (Rejected)

Ho3: There are no differences in life satisfaction between middle-aged women from different career sectors. (Rejected)

Ho4: There are no differences in life satisfaction between middle-aged women from different income levels. (Rejected)

In other words, there are differences in life satisfaction of women from different marital statuses, career sectors, and income levels. Meanwhile, another hypothesis fail to be rejected as the result showed that there is no difference in life satisfaction among women from different educational level-
Ho2: There are no differences in life satisfaction between middle-aged women from different educational levels (Fail to be rejected).

\section{Discussion}

Marital status is found to indicate differences in life satisfaction. Married women were reported to have higher life satisfaction than women who are single, divorced or widowed. This is supported by Joshua, et.al. (2011) who have found that being single gives bad impression towards life satisfactions. The study revealed that being alone without partners would further increase the level of stress among the respondents. Studies conducted on separations or divorced and life satisfactions in countries like the United States, United Kingdom, Switzerland and Russia also showed negative impact and were significant as well.

Nonetheless, other studies had shown that there were no differences in life satisfaction between women of different marital status. For example, Jan and Masood (2008) reported that there was no significant difference in the life satisfactions score between married, single and divorced women. This is because they have different life satisfactions' factors. For married women, the most important factors for life satisfactions are marriage 
and work satisfactions. This is different for single women who gave more attention on education and social activities in evaluating life satisfactions (Kousha and Moheen, 2004). They also have good social support and good relationship with their family members. Their life satisfactions are influenced by income and education (Newtson and Keith, 2001).

Education level was not found to contribute to life satisfaction. It may no longer be an issue to middle-aged or elderly women. After working for a long time, their experience helped them to improve their standard of living and income. Even with just SPM or STPM, they were still able to upgrade their skills and achievement through platforms provided by the government and private sectors such as promotion interviews, PTK examinations (for public servants), and skill courses. The platforms prepared enabled them to apply for promotions and salary increment in their respective sectors. Based on the statistics in 2014, a number of 1,596 ('000) women hold SPM certificate (Sijil Pelajaran Malaysial Malaysia Education Certificate) or equivalent. A significant number of women also reported to have Bachelor Degree (704 000), followed by 548000 of those who hold Diploma Degree (Department of Statistics, 2014). This statistics showed that women have a better education level in Malaysia. In fact, they have a better access to quality education, have better facilities and are encouraged to upgrade themselves. Nevertheless, the challenges and expectations they encountered as middle-aged women might weaken the impact of education on their life satisfaction.

This was consistent with the findings in Rayanagoudar, Gaonkar \& Itagi (2001) who reported that there was no difference in life satisfaction among women from different education background. This is also similar with Clark and Oswald (1994); Frey and Stutzer (2002) who suggested that education only contributes to life satisfaction through mediums, such as ambitions, income, social participation and self-confidence. Individuals with high education level, such as bachelor degree and masters, did not necessarily have high life satisfaction. Seldom, individuals with primary and secondary school education are more happy and satisfied with life compared to those with the background of university education.

The study also found that life satisfaction differed among women of different incomes. The finding indicated that life satisfaction could increase with the increase of income. The respondents of the study were working middle-aged women living in Hulu Langat, Selangor. Women in urban areas experienced more effects of inflation and price increase of items. Money is a focus in their lives in order to fulfil all life necessities, especially when they are the family breadwinner. Life becomes difficult when income is low, giving more negative effects to harmony in life and life satisfaction. Report by the Department of Statistics (2014) revealed that poverty in urban areas has dropped year by year, comparatively, in 2009, 2012 and 2014, the percentage of poverty rate declined from $1.7 \%$ to $1.0 \%$ and eventually to $0.3 \%$ in 2014 . For the overall population (rural and urban residents), it has dropped from $3.8 \%$ to $1.7 \%$ and $0.6 \%$ in 2014 . This is indeed an indicator of nation's wealth and prosperity.

It is consistent with the study by Easterlin, et.al. (2012); Jan and Masood (2008); Song and Appleton (2008) which stated that the higher the individual's income is, the higher his or her life satisfaction would be. Women with different income clearly experienced different life satisfaction. Unemployment on the other hand could reduce life satisfaction 
drastically (Song and Appleton, 2008). This showed that money had become a source for life satisfaction in this challenging age, where currency value kept on dwindling. Men and women struggle to upsurge their income in order to improve their status and quality of life. The increasing cost of living and utilities bills, children's school fees, housing and transportation loans, the inflation rate and many more affected income differently. People from high income group might not notice the increasing price of items compared to those with low income.

Household income of RM940 monthly is considered poor in urban areas, Peninsular Malaysia (Department of Statistics, 2014). Meanwhile, the household income of RM580 is categorized as very poor. Thus, these groups are entitled for monthly allowance from the government. Nevertheless, the percentage of poor residents in 2014 is low in Selangor, which is only $0.2 \%$ of the total population in Selangor. The average household income is RM8, 471 in urban areas in Selangor, compared to RM5, 272 for rural areas. It is the third in ranking compared to other states in Malaysia. Kuala Lumpur and Putrajaya marked the highest average of monthly household income, which is RM10, 629 and RM10, 401 respectively. Kuala Lumpur is the capital city of Malaysia and it is a prestigious city with high-end lifestyle and a bundle of job opportunities. Putrajaya on the other hand, is the government administrative city. It is the home for many civil servants and administrators. This city has been carefully designed for tourist attractions, with advanced amenities and beautiful landscape.

Career sector was also found to contribute to the different life satisfaction. The current study divided career into three categories, public, private and self-employed. The different career sector clearly showed different life satisfactions.
The public sector revealed the highest life satisfaction, followed by self-employed and private sector. This may be caused by the benefits entitled to public servants in the forms of financial security, medical benefits, numerous leave types, and allowance. The workload of public servants may be lighter compared to private sector workers. Self-employed women on the other hand experienced the advantage on time flexibility, financial freedom, autonomy, and many more. In U.S, public sector jobs accounted for $16.0 \%$ of total employment in 2013.

Rashid and Rashid (2012) demonstrated that employees' motivation was affected by the several work-related factors. Public sector employees were more motivated by work contents and experience. They enjoyed more balance between work and family life. However, private sector employees are more motivated by financial rewards, career development opportunities, and supportive environment (Rashid \& Rashid, 2012). It is apparent that public servants are less motivated by financial rewards than private sector employees. It is assumed that people who give high emphasis to pay will seek employment in the private sector, which is generally perceived to pay more than the public sectors for similar jobs (Lewis \& Frank 2002). Burgess and Ratto (2003) revealed that civil servants are motivated by other benefits and incentives than private sector workers. Therefore, women' career sectors, whether private or public might affect their happiness and life satisfaction. As the main focus of career women are career and family, the atmosphere they work in is vital.

The Department of Statistics (2014) reported that a high percentage of women in urban areas involved in manufacturing sectors. They are also participated in retail and wholesale business, food services, 
education, and social work. A remarkable percentage of them have joined public services as administrators and supporting staff. Some of those who are self-employed involved in selling and offering financial products, such as takaful, insurance, share and so forth. The challenging life in Selangor did really urge women from all age groups to strive for a better living by having higher income and more financial freedom. They have become more active in doing business and sales and become the breadwinner of the family. Women who are single or widowed have more pressure to survive especially if they have kids to take care of and nurture. This will greatly affect their life satisfaction as they hold major responsibilities.

\section{Limitations of Study}

The findings of this study can be generalized only to middle-aged women in Hulu Langat, Selangor. This study selected only middleaged career women as they share similar lifestyle, routines of life and commitments. The findings cannot be generalized to nonworking women who perhaps have different perspectives towards life and career. This study also focused on Malay women only as this enabled researcher to explore their unique views and perceptions. Malay women definitely hold different life orientation and ideology compared to non-Malay women. Future researches may examine and analyse life satisfaction of non-Malay women. Eventually, this study limit to districts in Selangor only to observe the impact of urbanization in Selangor to middle-aged career women. Women from other states may not experience the same challenges and pressures encountered by women in Selangor, and thus the results might be scattered. Further researches can study life satisfaction among women from other states, including Sabah and Sarawak as they may have different experience and expectations. It can also be studied qualitatively to have deeper understanding and more information about their life experience and life satisfaction, in specific.

\section{Conclusion}

To summarise, life satisfaction among middle-aged women varies depending on marital status, occupation, and income. Women of married status, working in public sectors with high income were reported to have highest life satisfaction. Women who are single/divorced/widowed, working in private sectors with low income on the other hand, reported to have low life satisfaction. It is evident that marital status, work and income play an important role in influencing life satisfaction among middle-aged women in Hulu Langat, Selangor. On the contrary, education does not significantly affect life satisfaction of women. Middle-aged women from different education backgrounds revealed an almost similar life satisfaction. University, secondary and primary education are not indicators of their life satisfaction.

The findings of this study clearly show that single/divorced/widowed women, low income and private sector employees should be given more attention. They reported a lower life satisfaction compared to the other groups. Emotional support, empathy and financial support are the main necessity to this group. Single mothers with low income are especially the ones with the most life struggles and highest pressure. The increasing living cost at urban areas would only worsen their emotional stability and life satisfactions. Thus, policy makers, psychologists, welfare workers and such can benefit from this study as it provides guidelines in making policies, programmes, 
and interventions to help middle-aged women. This group needs help as they are the foundation for public and family harmony.

Therefore, this study recommends that:

1. Single/divorced/widowed women have to be given special attention by the employer, community and the government. They are the groups that carry great responsibilities to take care of the families. They are the breadwinner of the family. Most of the times, single women receive less support from the employer and the community. Community should have funds to support this group of women, especially during critical times, such as before festive seasons.

2. Low income groups especially in urban areas have been greatly affected by the increasing cost of living. They have to pay a lot for the house rental, transportation charge and even educational fee. There should be more opportunities given to this group to start up small business. This group perhaps deserve a lower house rental, lower transportation charges, lower educational fee and so forth. Living in Selangor and other urban areas is very hard for this people.

3. Private workers need to be given a special care, especially those working in small companies. Their salaries are normally lower than public servants. They have higher workload and responsibilities. Most of the times, they cannot negotiate and demand for a better wage and a better work environment. At times, they have to work in a stressful and inconvenient environment. But, they need to stay and persevere to endure their life. This has profoundly affected their quality of life and life satisfaction. Government may establish few policies to ensure that their welfare can be safeguarded.

\section{References}

Adams, G.A., King, L.A., \& King, D.W. 1996. "Relationship of job and family involvement, family social support, and work-family conflict with job and life satisfaction". Journal of Applied Psychology, 81 (4), 411-420.http://dx.doi.org/10.1037/00219010.81.4.411.

Albert, I., Labs, K. \& Trommsdorff, G. 2010. "Are older adult German women satisfied with their lives? On the role of life domains, partnership status, and self-construal". The Journal of Gerontopsychology and Geriatric Psychiatry, 23 (1), 39-49.http:// dx.doi.org/10.1024/1662-9647/a000002.

Barrette, A.J. \& Murk, P.J. 2006. "Life Satisfaction Index for the Third Age (LSITA): A measurement of successful aging". In E.P. Isaac (Ed.). Proceedings of the 2006 Midwest Research-to-Practice Conference in Adult, Continuing, and Community Education (pp.7-12). St. Louis: University of Missouri, St. Louis.

Berg, J.A. 2011. "The stress of caregiving in midlife women". The Female Patient, 36, 33-35. http://citeseerx.ist.psu. edu/viewdoc/citations; jsessionid= 5F9867E2902D183EF482A99486E4527A?doi=10.1.1.370.8694.

Borg, C. Hallberg, I.R., \& Blomqvist, K. 2005. "Life satisfaction among older people with reduced self-care capacity: The relationship to social, health, and financial aspects". Journal of Clinical Nursing, 15, 607-618. http://www.readcube.com/articles/10.1111/ j.1365-2702.2006.01375.x.

Burgess, S., \& Ratto, M. 2003. "The role of incentives in the public sector: Issues and 
evidence". Oxford Review of Economic Policy, 19(2), 285-300.

Chappell, N.L. 1989. "Health and helping among the elderly". Journal of Aging and Health, 1, 102-120. http://doi. org/10.1177/089826438900100107.

Chipperfield, J.G., \& Havens, B. 2001. "Gender differences in the relationships between marital status transitions and life satisfaction in later life". Journal of Marriage and the Family, 12 (3), 176-186.

Clark, A. \& Oswald, A. 1994. "Unhappiness and unemployment". The Economic Journal, 104 (424), 648-659.http://doi. org/10.2307/2234639.

Costello, M.S. 2012. "The role of spirituality in the second half of life". Paper presented at Symposium at the Library of Congress, Washington, June.

Diener, E. D., Suh, E. M., Lucas. E. E. Smith, H. L. 1999. "Subjective Well-being: Three Decades of Progress". Psychological Bulletin. 125 (2), 276-302.

Easterlin, R.A., Morgan, R., Switek, M. \& Fei, W. 2012. "China's Life Satisfaction". Proceeding of the National Academy of Sciences of the United States of America, 109 (25), 9775-9780. http://doi. org/10.1073/pnas.1205672109.

Gee, E. M. \&Veevers, J.E. 1990. "Religious involvement and life satisfaction in Canada". Sociological Analysis, 51, 387394. http://doi.org/10.2307/3711079.

Gong, H., Cassells, R., \& Keegan, M. 2011. "Understanding life satisfaction and the education puzzle in Australia: A profile from HILDA Wave 9". NATSEM Working Paper 11/12, University of Canberra.

Frey, B.S. \& Stutzer, A. 2002. "What can economist learn from happiness research". Journal of Economic Literature, 40, 420435.
Hasnain, N., Ansari, S.A., \& Sethi, S. 2011. "Life satisfaction and self-esteem in married and unmarried working women". Journal of the Indian Academy of Applied Psychology, 37 (2), 316-319.

Hutchinson, G., Simeon, D.T., Bain, B.C., Wyatt, G.E., Tucker, M.B. \& Lefranc, E. 2004. "Social and Health determinants of well-being and life satisfaction in Jamaica". International Journal of Social Psychiatry, 50 (1), 43-53. http://doi. org/10.1177/0020764004040952.

Jan, M. \& Masood, T. 2008. "An assessment of life satisfaction among women". Extension and Communication, 2 (1), 33-42.

Jessica, K.M., Johnson, M., Pitt, E.B., Smyer, M. \& Matz-Costa, C. 2008. "Quality of employment and life satisfaction: A relationship that matters for older workers". Workplace Flexibility. The Center on Aging and Work.

Joshua, D., Joel, T.N., \& Meghan, R.L. 2011. "Sex difference in delaying family: Effects on job and life satisfaction". Psychology Research, 1(6), 444-452.

Kapteyn, A., Smith, J.P., \& Soest, A.V. 2009. "Life Satisfaction". Discussion paper no. 4015. IZA, The Netherlands.

Kim-Prieto, C., Diener, E., Tamir, M., Scollon, C. N., \& Diener, M. 2005. "Integrating the Diverse Definitions of Happiness: A TimeSequential Framework of Subjective WellBeing". Journal of Happiness Studies. 6 (3), 261-300.

Khoerun Nisa. 2014. "Sumber daya pensiun dan kepuasan hidup lansia pria dan wanita pada masa pension". Skripsi untuk Sarjana Sains, Fakultas Ekologi Manusia, Institut Pertanian Bogor.

Kong, F. \& You, X. 2013. "Loneliness and self-esteem as mediators between social support and life satisfaction in late adolescence". Social Indicator Research, 
110, 271-279. http://doi.org/10.1007/ sll205-001-9930-6.

Kousha, M. \& Moheen, N. 2004. "Predictors of life satisfaction among urban Iranian women: An exploratory analysis". Journal of Social Indicators Research, 40 (3), 320357.

KPWKM. 2015. "Perangkaan Wanita, Keluarga dan Masyarakat Malaysia 2015", Kementerian Pembangunan Wanita, Keluarga dan Masyarakat, Putrajaya. Retrieved from http://www.kpwkm.gov.my/ kpwkm/uploads/files/Penerbitan/Buku\%20 statistik/BUKU\%20STATISTIK \% 20 2015\%20KPWKM.pdf. Downloaded on 20 March 2017.

Leung, B. W. C, Moneta, G.B., \& Chang, C.M. 2005. "Think positively and feel positively: Optimism and life satisfaction in late life". International Journal of Aging and Human Development, 61 (4), 335-365.

Levinson, D. 1978. The Seasons of a Man's Life. New York: Knopf.

Lewis, G. B., \& Frank, S. A. 2002. "Who wants to work for the government?", Public Administration Review, 62 (4), 395-404.

Light, Hertsgaard, \& Martin. 1985. "Education and income: significant factors in life satisfaction of farm men and women". Research in Rural Education, 3 (1), 7-12.

Lora, E. \&Chaparo, J.C. 2008. The Conflictive Relationship between Satisfaction and Income. Inter-American Development Bank. Department of Investigation, Washington, New York.

Mahanta, D. \& Aggarwal, M. 2013. "Effect of perceived social support on life satisfaction of university students". European Academic Research, 1 (6), 1083-1094.

Meeks, S. \& Murrell, S.A. 2001. "Contribution of education to health and life satisfaction in older adults mediated by negative effect". JournalofAging Health, 13(1), 92-119.http:// doi.org/10.1177/089826430101300105.

NATSEM. 2010. "The Pursuit of Happiness: Life Satisfaction in Australia". NATSEM Income and Wealth Report. University of Canberra.

Navaie-Waliser, M., Spriggs, A., \& Feldman, P.H. (2002). Informal caregiving: Diferrential experiences by gender. Medical Care, 40 (12), 1249-1259.

Newtson, R. L., and P. M. Keith. 1997. "Single women in later life". In Handbook on women and aging, edited by J. M. Coyle, 385-99. Westport, Conn.: Greenwood Press.

Panda, A.K. 1999. Life Satisfaction among Elderly Females in Delhi. Department of Social Work, Delhi University, Unpublished manuscript.

Ramachandran, R., and Radhika, R. 2012. "Socioeconomic status and life satisfaction in cross cultural perspective: The elderly in Japan and India". International Journal of Humanities and Social Science, 2 (16), 285-297.

Rashid, S. \& Rashid, U. 2012. "Work Motivation Differences between Public and Private Sector". American International Journal of Social Science, 1 (2), 24-33.

Rayanagoudar, S., Gaonkar, V. \& Itagi, S.K. 2001. "Effect of income, education and religion on the life satisfaction of the elderly retired women". Man in India, 81, 301-304. Santrock, J.W. 2011. Life Span Development. New York: Mc Graw Hill.

Sener, A. 2011. "Emotional support exchange and life satisfaction". International Journal of Humanities and Social Science, 1(2), 79-88.

Sheldon, K.M., Elliot, A.J., Kim, Y. \& Kasser, T. 2001. "What is satisfying about satisfying events? Testing 10 candidate psychological needs". Journal of Personality and Social Psychology, 60, 570-585. http://dx.doi. org/10.1037. 
Shichman, S., \& Cooper, E. 2004. "Life satisfaction and sex role concept". Journal of Sex Role, 11, 227-240.

Song, L. \& Appleton, S. 2008. "Life satisfaction in Urban China: Components and determinants". World Development, 36 (11), 2325-2340.

Song, Y. I. 1992. "Life satisfaction of the KoreanAmerican elderly from a socio-psychological analysis". Journal of Population and Development, 21 (2), 225-241.

Sousa, L., \& Lyubomirsky, S. 2001. "Life Satisfaction". In J. Wore (ed). Encyclopedia of Women and Gender: Sex Similarities and Differences and the Impact of Society on Gender. New Jersey: Prentice Hall.

Suldo, S. M., \& Huebner, E. S. 2005. "Is Extremely High Life Satisfaction During Adolescence Advantageous?", Social Indicators Research. 78, 179-203.

The Department of Statistics 2014. "Data Asas Malaysia, Jabatan Perangkaan Malaysia, Putrajaya". Retrieved from http://www.rurallink.gov.my/wp-content/ uploads/2015/05/1-DATA-ASASMALAYSIA1.pdf. Downloaded on 27 March 2017.

Valois, R. F., Zullig, K. J., Huebner, S. E., Drane, J. W. 2004. "Life Satisfaction and Suicide Among High School Adolescents". Social Indicators Research, 66, 81-105.

Yamawaki, N., Nelson, J.A.P., \& Omori, M. 2011. "Self-esteem and life satisfaction as mediators between parental bonding and psychological well-being in Japanese Young adults". International Journal of Psychology and Counseling, 3 (1), 1-8.

Zhang, S., Erping, W., \& Chen, Y. 2011. "Relative deprivation based on occupation: An effective predictor of Chinese life satisfaction". Asian Journal of Social Psychology, 14, 148-158. http://doi. org/10.11111/j.1467-839x.2010.01338.x. 